\title{
ADHERENCE TO BIOLOGIC DRUGS AMONG PATIENTS WITH IMMUNE MEDIATED INFLAMMATORY DISEASES IN DUHOK GOVERNORATE
}

\author{
HALA F. KASIM, BSC (PHARM.)* \\ HISHYAR M. SALIH, MBCHB, MSC, PHD** \\ SOUZAN H. EASSA, B VMS, MSC, PHD $* * *$
}

Submitted 2 November 2019; accepted 24 December 2019

\begin{abstract}
Background: The need for ongoing treatment to manage immune-mediated inflammatory diseases is a challenge for health care providers, as there is always an attempt to achieve clinical remission as much as possible.

Objective: This study aimed to estimate the prevalence of non-adherence to biological drugs and factors affecting it among patients in Duhok governorate-Iraq.

Patients and Methods: A cross-sectional questionnaire-based study was conducted between December 2018 to October 2019 at the specialized center of rheumatic disease and medical rehabilitation in Duhok city. One hundred forty-four patients who lived in Duhok governorate out of 216 registered cases were included, each with the established disease for at least 12 months, and had been taking biological drugs (Etanercept, Infliximab, and Adalimumab) with or without conventional drugs for at least three months were involved in this study. Disease activity scales as appropriate to each disease were used, with using a medication adherence scale to assess the adherence to medications.
\end{abstract}

Results: From the total of 144 patients included in this study, 134 (93.1\%) of them were nonadherent compared to only $10(6.9 \%)$ of patients who were adherent to medication intake. Significant associations existed between adherence to the medications and different factors. These factors with the corresponding percentages of non-adherence were as follows: age between 30-39 (34.3\%), illiterate/ primary education (56.0\%), unemployed (64.9\%), no ability to buy biologic drugs $(82.1 \%)$, etanercept users $(71.6 \%)$ and $(56.7 \%)$ were using biological drugs for less than four years.

Conclusion and recommendation: With the existence of multiple factors effect on adherence to medications and due to the inconsistency of these factors, routine measurements of adherence to medications are essential in achieving the desired therapeutic goal.

Duhok Med J 2020; 14 (1): 63-76.

Keywords: Adherence, biological drugs, medication adherence scale

\section{7 he requirement of immune-mediated inflammatory diseases (IMIDs),}

which involve rheumatoid arthritis (RA), ankylosing spondylitis (AS), psoriasis (PsO), psoriatic arthritis (PsA) and inflammatory bowel disease (IBD) particularly Crohn's disease (CD) and ulcerative colitis $(\mathrm{UC})^{1}$ to the persisting management makes adherence to therapeutics regimen essential and forms a critical challenge facing the health-care providers ${ }^{2,3}$. Non-adherences to treatment results in enhancement and recurrence of the disease activity, decrease the efficacy of treatment, reducing the quality of life and even results in increased use of

\footnotetext{
*As is. Lecturer, Department of Clinical Pharmacy, College of the Pharmacy, University of Mosul, Mosul, Iraq.

** Lecturer, Department of Clinical Pharmacy, College of the Pharmacy, University of Duhok,

*** Assistant Prof, Department of Anatomy and Biology, College of Medicine, University of Duhok, Kurdistan Region, Iraq.

Correspondence author: Hala F.Kasim, halafouad9011@yahoo.com, Mobil+7702003332.
} 
resource and costs of the health-care system $^{2}$.

The definition of medication adherence, as reported by the World Health Organization (WHO) is "the degree to which the behavior of the patient in terms of medication, following of a diet or changes in lifestyle is consistent with the recommendations agreed with the healthcare professional"4. The reported adherence rates of IMIDs, based on methods of assessing the adherence and drugs taken, are as follow: RA (21-99\%), $\mathrm{PsO}(22-67 \%), \mathrm{CD}$ or UC $(28-96 \%) 2$. It exceeded $100 \%$ when there was taking more than the prescribed amounts of drugs 5 . Good adherence is about taking off $80 \%$ or more of prescribed drugs over the length of study 5 .

The presence of multifactorial barriers to adherence and changing of these factors over the course of the disease need longterm use of pharmacotherapy ${ }^{6}$. WHO has identified several factors associated with non-adherence; social-economic, healthcare system, condition, therapy, and patient-related factors ${ }^{6}$. Based on patient's attitude, non-adherence to treatment can be either non-intentional when there is an intention to take the drug, but the patient cannot take it because of forgetting, complex therapeutics regimen or inability to buying the drug and the intentional type, based on a decision made by the patient about stopping their medication or modifying the dosage regimen, depending on patient's belief ${ }^{4,6}$.

Methods of assessment the adherence sit a challenge, as there is a requirement for a method that is ideal, simple, valid, reliable, reproducible, and has specificity to any changes in adherence ${ }^{7}$. Recently, there is no single method with such characteristics, but more than one method exists, each with unique characteristics and limitations ${ }^{7}$. The available methods are (1) Subjective; the simplest method, often used, includes self-report by patient and estimation by the physicians of patients' adherence. (2) Direct objective; methods of measuring and monitoring serum drug/ metabolite levels or biological markers. (3) Indirect, the most commonly used and include pharmacy refills, electronic monitoring, tablet counts, and questionnaires $^{6}$. The current study was undertaken to identify the most common factors of non-adherence to biological drugs by using the indirect method through face to face reported questionnaire.

\section{PATIENTS AND METHODS}

A cross-sectional questionnaire-based study was conducted between December 2018 to October 2019 at the specialized center of rheumatic disease and medical rehabilitation in Duhok governorate IraqKurdistan Region according to the scheduled visit of the center and approved by the local ethical committee (decision number: 27112018-9/03.11.2019).

A total of 144 out of 216 patients registered in the center were included in this study according to the inclusion criteria which include: patient who lived in Duhok governorate of either gender with established IMIDs for at least 12 months and had been taking for at least three months a biological drugs (etanercept, infliximab or adalimumab) with or without conventional drugs like, steroids, nonsteroidal anti-inflammatory drugs (NSAIDs) and other disease modifying anti-rheumatic drugs. 
Demographics and clinical characteristics of the patients were recorded either from patients themselves or from their clinical file, and the study also assesses adherence to medication according to the disease activity statues, Patient Activity Scale-II (PAS-II) as recommended by the American College of Rheumatology (ACR) was used to assess most recent disease activity of rheumatic diseases ${ }^{8}$, Crohn's Disease Activity Index (CDAI) ${ }^{9}$ for $\mathrm{CD}$ and partial Mayo score(PMS $)^{10}$ for UC. The sources for scales' items and their calculations were available online ${ }^{11,12}$. After that, categorization of the patients into two groups as remission/low or minimum disease activity (LDA)group and moderate disease activity (MDA)/high disease activity (HDA) group.

The medication adherence scale (MAS) in the Kurdish version was used to assess adherence. The scale's questionnaire was translated into the Kurdish language by two bilingual Kurdish lecturers, according to international guidelines at the college of pharmacy/ University of Duhok (UOD), to eliminate any error that may occur ${ }^{13,14,15}$. The content validity (face validity) of the language appropriateness was performed by a group of the specialist; three of them were from the college of pharmacy/UOD. This scale was similar to the English/ Arabic version of the Iraqi Anti-Diabetic Medication Adherence Scale ${ }^{16}$. It had 8 items, the question one to three answered on a 5-point Likert's scale; never $=1.00$, rarely $=0.75$, sometimes $=0.50$, most times $=0.25$ and always $=0.00)^{16}$. While the question four to eight had either yes or no answer; yes $=0$ and no=1 except for question four where yes $=1$ and no=0, the total score was range from 0 to $8 ;<6=$ low adherence, $6-<8=$ medium adherence and $8=$ high adherence. Patients who had a low or a moderate rate of adherence were considered as non-adherent ${ }^{16}$.

\section{STATISTICAL ANALYSES}

By using SPSS 24, statistical software for the description of data in terms of mean, standard deviation (SD), frequency (Freq.) and percentage $(\%)$. Using the chi-square (X2) test to assess significance between categorical variables. Where applicable pvalue of $\leq 0.05$ was considered as statistically significant.

\section{RESULTS}

The mean age of the study group $(n=144)$ was $(41.81 \pm 12.16$ year $),(54.9 \%)$ was either illiterate or had primary education, $(61.8 \%)$ was unemployed, $(78.5 \%)$ had no ability to buy biological drugs and (66.7\%) was non-smokers (Table 1). As shown in table 2, (44.4\%) of males aged between (30-39) years old and (27.8\%) of females aged between (50-59) years old. While the diagnosis of the study group (table 2) were either RA (41.7\%), AS (38.9\%) and other conditions (19.4\%); either non-specific spondyloarthritis, seronegative arthritis, PsA, CD, UC and enteropathic arthritis, where $(73.6 \%)$ of males had AS, and (77.8\%) of females had RA. 
ADHERENCE TO BIOLOGIC DRUGS AMONG PATIENTS WITH IMMUNE

Table 1: Socio-demographic characteristics of the study group, $(n=144)$

\begin{tabular}{ll}
\hline Items & Freq. $(\%)$ \\
\hline Age (years) & $41.81 \pm 12.16$ \\
Mean \pm SD & $(69-20=49)$ \\
(range) & $79(54.9 \%)$ \\
\hline Educational status & $36(25.0 \%)$ \\
Illiterate/primary & $29(20.1 \%)$ \\
Intermediate/secondary & \\
Institute/univers ity & $89(61.8 \%)$ \\
\hline Employment status & $55(38.2 \%)$ \\
Unemployed & $31(21.5 \%)$ \\
Employed & $113(78.5 \%)$ \\
\hline Ability to buy biologic drugs & $48(33.3 \%)$ \\
Yes, sometimes & $96(66.7 \%)$ \\
No &
\end{tabular}

Freq.: frequency, \%: percentage, $n=$ patient number.

Table 2: Diagnosis of rheumatoid arthritis (RA), ankylosing spondylitis (AS) andother clinical conditions with their age distribution among males and females of the study group $(n=144)$.

\begin{tabular}{ccccc}
\hline Items & & $\begin{array}{c}\text { Male } \\
\text { Freq. (\%) }\end{array}$ & $\begin{array}{c}\text { Female } \\
\text { Freq. (\%) }\end{array}$ & $\begin{array}{c}\text { Total } \\
\text { Freq. (\%) }\end{array}$ \\
Age range (years) & $\mathbf{2 0 - 2 9}$ & $17(23.6 \%)$ & $4(5.6 \%)$ & $21(14.5 \%)$ \\
& $\mathbf{3 0 - 3 9}$ & $32(44.4 \%)$ & $18(25.0 \%)$ & $50(34.7 \%)$ \\
& $\mathbf{4 0 - 4 9}$ & $13(18.1 \%)$ & $17(23.6 \%)$ & $30(21.0 \%)$ \\
& $\mathbf{5 0 - 5 9}$ & $8(11.1 \%)$ & $20(27.8 \%)$ & $28(19.4 \%)$ \\
Diagnosis & $\mathbf{6 0 - 6 9}$ & $2(2.8 \%)$ & $13(18.0 \%)$ & $15(10.4 \%)$ \\
& Total & $72(100.0 \%)$ & $72(100.0 \%)$ & $144(100.0 \%)$ \\
& RA & $4(5.6 \%)$ & $56(77.8 \%)$ & $60(41.7 \%)$ \\
& AS & $53(73.6 \%)$ & $3(4.2 \%)$ & $56(38.9 \%)$ \\
& $*$ Others & $15(20.8 \%)$ & $13(18.0 \%)$ & $28(19.4 \%)$ \\
\cline { 2 - 5 } & Total & $72(100.0 \%)$ & $72(100.0 \%)$ & $144(100.0 \%)$ \\
\hline
\end{tabular}

Freq.: frequency, \%: percentage, $n=$ patient number.

* Others :non-specific spondyloarthritis, seronegative arthritis, psoriatic arthritis, Crohn's disease, ulcerative colitis and enteropathic arthritis.

Table 3 illustrates $(61.1 \%)$ had no family history, $(40.3 \%)$ had a disease duration of more than or equal to 10 years and (60.4\%) had MDA/ HDA status, the results of PAS II, CDAI, and PMS scales as appropriate to their clinical conditions. The majority of patients $(69.4 \%)$ were on etanercept with $(87.5 \%)$ having a history of using csDMARDs and (59.0\%) started receiving the biological drugs and used it 
for less than four years from the center. Also, it was found that $(70.1 \%)$ of patients were on polypharmacy therapy other than or in addition to biological drugs, which were either NSAIDs, prednisolone and/ or
csDMARDs such as methotrexate, sulfasalazine, azathioprine, leflunomide and hydroxychloroquine. Only (36.8\%) of patients were suffering from biological drugs' adverse effects.

\begin{tabular}{lc}
\hline \multicolumn{1}{c}{ Table 3: Clinical characteristics and drug-related factors of the study group, $\mathbf{n}=\mathbf{1 4 4}$} \\
\hline Items & Freq. $(\boldsymbol{\%})$ \\
\hline Family history & $56(38.9 \%)$ \\
Yes & $88(61.1 \%)$ \\
No & $41(28.5 \%)$ \\
\hline Duration of disease & $45(31.2 \%)$ \\
1-4 years & $58(40.3 \%)$ \\
5-9 years & $57(39.6 \%)$ \\
10 years and more & $87(60.4 \%)$ \\
\hline Disease activity status & $100(69.4 \%)$ \\
Remission/low & $37(25.7 \%)$ \\
Moderate/high & $7(4.9 \%)$ \\
\hline Type of biologic drugs taken & $126(87.5 \%)$ \\
Etanercept & $18(12.5 \%)$ \\
Infliximab & \\
Adalimumab & $59(41.0 \%)$ \\
\hline Past DMARDs history & $85(59.0 \%)$ \\
csDMARDs & $101(70.1 \%)$ \\
Biological drugs\& csDMARDs & $43(29.9 \%)$ \\
\hline Duration of using biological drugs & $53(36.8 \%)$ \\
$\geq 4$ years & $91(63.2 \%)$ \\
\hline 4 years & \\
\hline Polypharmacy & \\
No & \\
\hline Biological drugs adverse effects & \\
Yes & \\
No & \\
\hline Fes. & \\
\hline
\end{tabular}

Freq.: frequency, \%: percentage, $\mathrm{n}=$ patient number. csDMARDs: conventional synthetic disease-modifying anti-rheumatic drugs.

By using MAS, (49.3\%) of patients had low adherence, $(43.8 \%)$ had medium adherence and $(6.9 \%)$ had high adherence both low and medium adherences were considered as non-adherence, while the main reasons for non-adherence were shown in (table 4). 
ADHERENCE TO BIOLOGIC DRUGS AMONG PATIENTS WITH IMMUNE

Table 4: Adherence items among study groups using medication adherence scale (MAS), n=144.

\section{Adherence items}

\section{Freq. (\%)}

1. In the last month, how often did you forget to take your medication(s)?

$\begin{array}{lr}\text { Always } & 7(4.9 \%) \\ \text { Most times } & 0(0.0 \%) \\ \text { Sometimes } & 37(25.7 \%) \\ \text { Rarely } & 7(4.9 \%) \\ \text { Never } & 93(64.5 \%)\end{array}$

2. In the last month, how often did you intend to take your medication(s) in doses different from what has been prescribed?

Never $\quad 144$

$(100.0 \%)$

3. In the last month, how often did you intend to take your medication (s) in a time different from what has been prescribed?

Always

30

(20.8\%)

Most times 57

(39.6\%)

Sometimes $\quad 38(26.4 \%)$

Rarely

$0(0.0 \%)$

Never

$19(13.2 \%)$

4. In the last month, did you take your medication(s) with you when you are away from home (e.g., traveling or visiting relatives)?

Yes

108

$(75.0 \%)$

No 36

$(25.0 \%)$

5. In the last month, did you stop taking your Yes 31 medication (s) without consulting a physician because of medication side effects?

(21.5\%)

No

$(78.5 \%)$

6. In the last month, did you take less of your medication ( $\mathrm{s}$ ) without consulting a physician because you feel better?

Yes 28

$(19.4 \%)$

No

$(80.6 \%)$

7. During sick days (e.g., flu, and diarrhea), did you take less of your medication (s) without consulting a physician due to reduced appetite?

No $(100.0 \%)$

8. In the last month, did you take less of your medication ( $\mathrm{s}$ ) without consulting a physician because of a high medication cost?

\section{Yes}

$(83.3 \%)$

No

(16.7\%)
144

120

24
Significant association $(\mathrm{p} \leq 0.05)$ was found between adherence to biological drugs and variable factors as demonstrated by (table $5)$, age of patients showed a significant association $(\mathrm{p} \leq 0.05)$ with adherence to a biological drug, more non-adherence were reported in patients whom age between (30-39) years $(34.3 \%)$. While concerning educational status and employment status, a significant association $(\mathrm{p} \leq 0.05)$ of nonadherence to biological drugs were reported among patients with either 


\begin{tabular}{|c|c|c|c|c|}
\hline \multicolumn{2}{|c|}{ Duhok Medical Journal } & & \multicolumn{2}{|c|}{ Volume 14, Issue 1,2020} \\
\hline \multicolumn{2}{|c|}{$\begin{array}{l}\text { illiterate/ primary education and } \\
\text { unemployed respectively }(56.0 \%, 64.9 \%) \text {. } \\
\text { A highly significant association of non- }\end{array}$} & \multicolumn{3}{|c|}{$\begin{array}{l}\text { adherent to medication }(\mathrm{p} \leq 0.001) \text { was als } \\
\text { related to the inability of patients to bu. } \\
\text { biological drugs }(82.1 \%) \text {. }\end{array}$} \\
\hline \multirow{3}{*}{ Variables } & \multicolumn{4}{|c|}{ Adherence to DMARDs using MAS } \\
\hline & \multirow{2}{*}{$\begin{array}{c}\text { Non-adherence } \\
134(93.1 \%)\end{array}$} & \multirow{2}{*}{$\begin{array}{c}\text { Adherence } \\
10(6.9 \%) \\
\end{array}$} & \multicolumn{2}{|c|}{ Test of s ignificance } \\
\hline & & & $\mathrm{X}^{2}$ (d.f.) & p-value \\
\hline $\begin{array}{l}\text { Age range (years) } \\
20-29 \\
30-39 \\
40-49 \\
50-59 \\
60-69\end{array}$ & $\begin{array}{l}16(12.0 \%) \\
46(34.3 \%) \\
29(21.6 \%) \\
28(20.9 \%) \\
15(11.2 \%)\end{array}$ & $\begin{array}{c}5(50.0 \%) \\
4(40.0 \% \\
1(10.0 \%) \\
0(0.0 \%) \\
0(0.0 \%)\end{array}$ & $13.144(4)$ & 0.011 \\
\hline $\begin{array}{l}\text { Gender } \\
\text { Male } \\
\text { Female }\end{array}$ & $\begin{array}{l}65(48.5 \%) \\
69(51.5 \%)\end{array}$ & $\begin{array}{l}7(70.0 \%) \\
3(30.0 \%)\end{array}$ & $1.719(1)$ & 0.190 \\
\hline \multicolumn{5}{|l|}{ Educational status } \\
\hline $\begin{array}{l}\text { Illiterate/Primary } \\
\text { Intermediate/Secondary } \\
\text { Institute/university }\end{array}$ & $\begin{array}{l}75(56.0 \%) \\
35(26.1 \%) \\
24(17.9 \%)\end{array}$ & $\begin{array}{l}4(40.0 \%) \\
1(10.0 \%) \\
5(50.0 \%)\end{array}$ & $6.158(2)$ & 0.046 \\
\hline \multicolumn{5}{|l|}{ Employment status } \\
\hline Unemployed & $87(64.9 \%)$ & $2(20.0 \%)$ & \multirow[t]{2}{*}{$7.956(1)$} & \multirow[t]{2}{*}{0.005} \\
\hline Employed & $47(35.1 \%)$ & $8(80.0 \%)$ & & \\
\hline $\begin{array}{l}\text { Ability to buy biologic drugs } \\
\text { Yes, sometimes } \\
\text { No }\end{array}$ & $\begin{array}{c}24(17.9 \%) \\
110(82.1 \%)\end{array}$ & $\begin{array}{l}7(70.0 \%) \\
3(30.0 \%)\end{array}$ & $14.946(1)$ & $<0.001$ \\
\hline $\begin{array}{l}\text { Smoking status } \\
\text { Yes } \\
\text { No }\end{array}$ & $\begin{array}{l}45(33.6 \%) \\
89(66.4 \%)\end{array}$ & $\begin{array}{l}3(30.0 \%) \\
7(70.0 \%)\end{array}$ & $0.054(1)$ & 0.817 \\
\hline
\end{tabular}

$\mathrm{n}=$ patient number, $\mathrm{X}^{2}$ : chi-square test, d.f.: the degree of freedom, DMARDs: diseasemodifying anti-rheumatic drugs, MAS: medication adherence scale. Percent $(\%)$ within the level of adherence.

Table 6 shows that both type of biologic drugs used and the duration of taking these medication significantly association $(\mathrm{p} \leq 0.05)$ with adherence to medication, where $(71.6 \%)$ of the non-adherent patient was on etanercept in compared to $(25.4 \%)$ on infliximab and $(3.0 \%)$ on adalimumab, while the rate of non-adherence increase as the duration of using biological is reduced. 
ADHERENCE TO BIOLOGIC DRUGS AMONG PATIENTS WITH IMMUNE

Table 6: Clinical and drug factors affecting adherence among the study group $(n=144)$. Variables

Adherence to DMARDs using MAS

\begin{tabular}{|c|c|c|c|c|}
\hline & \multirow{2}{*}{$\begin{array}{c}\text { Non- } \\
\text { adherence } 134 \\
(93.1 \%)\end{array}$} & \multirow{2}{*}{$\begin{array}{c}\text { Adherence } \\
10(6.9 \%)\end{array}$} & \multicolumn{2}{|c|}{ Test of significance } \\
\hline & & & $X^{2}$ (d.f.) & p-value \\
\hline $\begin{array}{l}\text { Diagnos is } \\
\text { RA } \\
\text { AS } \\
\text { Others }\end{array}$ & $\begin{array}{l}57(42.5 \%) \\
52(38.8 \%) \\
25(18.7 \%)\end{array}$ & $\begin{array}{l}3(30.0 \%) \\
4(40.0 \%) \\
3(30.0 \%)\end{array}$ & $\begin{array}{c}0.970 \\
(2)\end{array}$ & 0.616 \\
\hline $\begin{array}{l}\text { Dis e ase activity } \\
\text { Status } \\
\text { Remission/low } \\
\text { Moderate/high }\end{array}$ & $\begin{array}{l}52(38.8 \%) \\
82(61.2 \%)\end{array}$ & $\begin{array}{l}5(50.0 \%) \\
5(50.0 \%)\end{array}$ & $\begin{array}{c}0.488 \\
(1)\end{array}$ & 0.485 \\
\hline $\begin{array}{l}\text { Duration of disease } \\
1-4 \text { years } \\
5-9 \text { years } \\
10 \text { years and more }\end{array}$ & $\begin{array}{l}38(28.4 \%) \\
42(31.3 \%) \\
54(40.3 \%)\end{array}$ & $\begin{array}{l}3(30.0 \%) \\
3(30.0 \%) \\
4(40.0 \%)\end{array}$ & $\begin{array}{c}0.014 \\
(2)\end{array}$ & 0.993 \\
\hline $\begin{array}{l}\text { Side effects } \\
\text { Yes } \\
\text { No }\end{array}$ & $\begin{array}{l}50(37.3 \%) \\
84(62.7 \%)\end{array}$ & $\begin{array}{l}3(30.0 \%) \\
7(70.0 \%)\end{array}$ & $\begin{array}{c}0.214 \\
(1)\end{array}$ & 0.644 \\
\hline $\begin{array}{l}\text { Polypharmacy } \\
\text { Yes } \\
\text { No }\end{array}$ & $\begin{array}{l}95(70.9 \%) \\
39(29.1 \%)\end{array}$ & $\begin{array}{l}6(60.0 \%) \\
4(40.0 \%)\end{array}$ & $\begin{array}{c}0.527 \\
(1)\end{array}$ & 0.468 \\
\hline $\begin{array}{l}\text { Type of biologic } \\
\text { drugs taken } \\
\text { Etanercept } \\
\text { Infliximab } \\
\text { Adalimumab }\end{array}$ & $\begin{array}{c}96(71.6 \%) \\
34(25.4 \%) \\
4(3.0 \%)\end{array}$ & $\begin{array}{l}4(40.0 \%) \\
3(30.0 \%) \\
3(30.0 \%)\end{array}$ & $\begin{array}{c}15.390 \\
(2)\end{array}$ & $<0.001$ \\
\hline $\begin{array}{l}\text { Duration of using } \\
\text { biological drugs } \\
\geq 4 \text { years } \\
<4 \text { years }\end{array}$ & $\begin{array}{c}58 \\
(43.3 \%) \\
76(56.7 \%)\end{array}$ & $\begin{array}{l}1(10.0 \%) \\
9(90.0 \%)\end{array}$ & $\begin{array}{c}4.262 \\
(1)\end{array}$ & $\mathbf{0 . 0 3 9}$ \\
\hline
\end{tabular}

$\mathrm{n}=$ patient number, $\mathrm{X}^{2}$ : chi-square test, d.f.: the degree of freedom. RA: rheumatoid arthritis, AS: ankylosing spondylitis, DMARDs: disease-modifying anti-rheumatic drugs, MAS: medication adherence scale. Percent (\%) within the level of adherence.

\section{DISCUSSION}

The fluctuation of factors that are associated with non-adherence through the course of the disease makes the recognition of non-adherence patients helpful to health-care providers in achieving target treatment ${ }^{17}$. According to the main factors identified by WHO that related to non-adherence ${ }^{6}$, beginning with socio-economic factors, this study showed that young age patients; between (30-39) years demonstrated a higher rate of non- 
adherence to biological drugs comparing to other age groups, this is similar to that what have been reported by Goh et al, (2017), who stated that younger patients had less adherence with medication than older patients, while two studies conducted in Egypt ${ }^{19,20}$ showed that younger age was more adherent, this dissimilarity due to considering age as inconsistent factors that influenced by other confounding factors such as presence of comorbidities and complexity of the medical regimens which often associated with older age ${ }^{6}$ and may be due to active lifestyle of younger patients making them pay less attention to their clinical illness ${ }^{21}$.

No association between gender and adherence to biological drugs found in this study which is similar to the Iranian study about adherence to chronic illness that found gender as an unessential factor affecting medication adherence ${ }^{22}$, in contrast to the Indian study that found female gender as main determinate of none-adherence ${ }^{23}$.

A significant association between level of education and adherence to biological drugs that found in this study is similar to the Egyptian study ${ }^{20}$ that explain this association by a difficult understanding of medical instructions and unrecognition of a potential problem that is associated with non-adherence to therapeutic regimen by patients with a low level of education. A significant association in this study is found between employment status and ability to buy biological drugs with adherence to biological drugs, the effect of this economic factor on adherence to medications can be explained by the available health-care system and the methods of supplying drugs were whether depend on financial resources of patients' or $\operatorname{not}^{21,24}$. The fact that these biological drugs are very expensive, that cannot be provided regularly by this center, and patients' ability to buying these drugs is limited. Cost of drugs and its association with adherence is also found in other studies $^{19,22}$ and considered as a significant problem affect adherence since most patients require using biological drugs for longer period, if not for their entire life span in addition to the need of using multiple drugs for their rheumatoid conditions $^{18}$ and inconsistently to this therapeutic regimen exposes the patients to a high risk of treatment failure and then recurrence of the disease, as a successful treatment based on confirming long-term biologic drug adherence ${ }^{25}$. Although no significant association was founded in this study between smoking status and adherence to biological drugs, this factor is considered as changeable factor affecting adherence to medications like other sociodemographical factors ${ }^{1,6,21}$ and the findings of these factors are often difficult to recognize because of close association with inter-related barriers that affect the achievement of complete care ${ }^{17}$ with being subjected to a cultural difference between study groups ${ }^{24}$.

In concern with condition/clinical relatedfactors, in this study, it was found no association between type of disease, disease activity status and disease duration with adherence to biological drugs, while other studies illustrated that a shorter duration of disease and lower activity status, better mental health can be achieved which helps in achieving a better adherence $^{17}$. Although both disease duration, disease activity and its 
association with adherence were the most frequent clinical factors examined through studies, diversity and inconsistently of this association were also identified ${ }^{1,6}$.

Class of drugs, dosage form, methods, and frequency of administration, polypharmacy, and occurrence of side effects can consider as a determinant of adherence to treatment as therapy-related factors 17, that in this study it was found a significant association between type of biological drugs used and adherence to medication, where majority of nonadherent patients were using etanercept, similar to what reported by few studies that users of infliximab were more adherent than users of etanercept which might be due to that intravenous infusion administration at wider intervals schedule in outpatient setting comparing to subcutaneous self-administration of etanercept at shorter intervals25. No association was found in this study between the occurrence of Adverse effects and using of polypharmacy with adherence to DMARDs, this opposite to what found in other studies ${ }^{4,19}$. While a significant association between duration of using biological drugs with adherence to biological drugs is found in this study, where a high percent of non-adherent patients was using biological drugs for short period, this finding can be explained by a non-confidence and incomplete knowledge experienced by new patients to this type of therapeutic regimen comparing to older patients and can be considered as one of the patient-related factors that affect adherence to medication, therefore enhancing patients' education and belief concerning their disease and the required treatment shows a good effect on adherence behavior of the patient ${ }^{6}$.

In general, the existence of vast differences in the adherence rate among studies can be explained by a variation in study populations, methods of assessing adherence, types of drug used, and source of data. ${ }^{17,25}$ The main limitation of this study is the source of data depends on the questionnaire, which subjected to response bias. To our knowledge this is the first study about non-adherence to biological drugs conducted in this city, hoping not to be the last, as a routine measuring of adherence in clinical practice and then identifying the most factors affecting adherence can help in planning strategies aimed at achieving both better adherence and clinical outcomes ${ }^{4}$.

With the existence of multiple factors effect on adherence to medications; age, level of education, the economic factor that includes employment status, ability to buy biologic drugs by patients and offering medications regularly to patients by the health-care system, in addition to the type and duration of biological drugs used. Due to the inconsistency of these factors, routine measurements of adherence to medications are essential in achieving the desired therapeutic goal.

\section{ACKNOWLEDGMENTS}

We want to thank the staff of the medical center, particularly Dr. Mohamed Taher Rasol and Bilind Hassan Sharaf for helping us to accomplish this work.

\section{CONFLICT OF INTEREST}

The authors declared that they have no conflict of interest. 


\section{REFERENCES}

1. Vangeli E, Bakhshi S, Baker A, Fisher A, Bucknor D, Mrowietz U, et al. A systematic review of factors associated with non-adherence to treatment for immune-mediated inflammatory diseases. Advances in therapy. 2015; 32(11): 983-1028.

2. Michetti P, Weinman J, Mrowietz U, Smolen J, Peyrin-Biroulet L, Louis E, et al. Impact of treatment-related beliefs on medication adherence in immune-mediated inflammatory diseases: Results of the Global ALIGN study. Advances in therapy. 2017; 34 (1): 91-108.

3. Lavielle M, Puyraimond-Zemmour D, Romand X, Gossec L, Senbel E, Pouplin S, et al. Methods to improve medication adherence in patients with chronic inflammatory rheumatic diseases: A systematic literature review. RMD Open. 2018; 4(2): e000684.

4. Rincón-Rincón JR, Jaimes Fernández DA, García-Casallas JC, Beltránd A, Télleze A, Fernández-Ávila DG, et al. Methods for measuring adherence to oral disease-modifying drugs in rheumatoid arthritis and factors associated with low adherence to pharmacological treatment.Revista Colombiana de Reumatología. 2018; 25(4): 261-270.

5. Salt E, Frazier SK. Predictors of medication adherence in patients with rheumatoid arthritis. Drug development research. 2011; 72(8): 756-63.

6. Van Den Bemt BJ, Zwikker HE, van den Ende $\mathrm{CH}$. Medication adherence in patients with rheumatoid arthritis:
A critical appraisal of the existing literature. Expert Review of Clinical Immunology. 2012; 8(4): 337-51.

7. Lehmann A, Aslani P, Ahmed R, Celio J, Gauchet A, Bedouch P, et al. Assessing medication adherence: Options to consider. International journal of clinical pharmacy. 2014; 36(1): 55-69.

8. Anderson J, Caplan L, Yazdany J, Robbins ML, Neogi T, Michaud K, et al. Rheumatoid arthritis disease activity measures: American college of rheumatology recommendations for use in clinical practice. Arthritis care \& research. 2012; 64(5): 640-7.

9. Sehgal R, Koltun WA. Scoring systems in inflammatory bowel disease. Expert review of gastroenterology \& hepatology. 2010; 4(4): 513-21.

10. Lewis JD, Chuai S, Nessel L, Lichtenstein GR, Aberra FN, Ellenberg JH. Use of the noninvasive components of the Mayo score to assess clinical response in ulcerative colitis. Inflammatory bowel diseases. 2008; 14(12): 1660-6.

11. MDCalc: Patient Activity Scale II (PAS II) for RA [Internet]. U.S.: Medical calculator; c2005-2019 [cited 2019 July 1]. Available from: https://www.mdcalc.com/patientactivity-scale-ii-pas-ii-ra\#evidence.

12. IG-IBD: Calculators in gastroenterology [Internet]. Florence (Italy): The Italian group for inflammatory bowel disease; [cited 2019 July 20]. Available from: https://www.igibdscores.it/en/scorecdai.html 
13. Guillemin F, Bombardier C, Beaton D. Cross-cultural adaptation of healthrelated quality of life measures: literature review and proposed guidelines. Journal of clinical epidemiology. 1993; 46(12): 1417-32.

14. Wild D, Grove A, Martin M, Eremenco S, McElroy S, VerjeeLorenz A, et al. Principles of good practice for the translation and cultural adaptation process for patient-reported outcomes (PRO) Measures: report of the ISPOR task force for translation and cultural adaptation. Value in Health. 2005; 8(2): 94-104.

15. Del Greco L, Walop W, Eastridge L. Questionnaire development: 3. Translation. CMAJ: Canadian Medical Association Journal. 1987; 136(8): 817-8.

16. Mikhael EM, Hussain SA, Shawky N, Hassali MA. Validity and reliability of anti-diabetic medication adherence scale among patients with diabetes in Baghdad, Iraq: a pilot study. BMJ Open Diabetes Research and Care. 2019; 7(1): 1-7.

17. Marengo MF, Suarez-Almazor ME. Improving treatment adherence in patients with rheumatoid arthritis: what are the options?.International journal of clinical rheumatology. 2015; 10(5): 345-56.

18. Goh H, Kwan YH, Seah Y, Low LL, Fong W, Thumboo J. A systematic review of the barriers affecting medication adherence in patients with rheumatic diseases. Rheumatology international. 2017; 37(10): 1619-628.

19. Gadallah MA, Boulos DNK, Dewedar S, Gebrel A, Morisky DE. Assessment of rheumatoid arthritis patients' adherence to treatment. The American journal of the medical sciences. 2015; 349(2): 151-6.

20. Alhefny AE, Abd El-Rahman M, Abd El-Moteleb S, Sakr H, Hassan R. Evaluation of adherence to drug treatment in patients with rheumatoid arthritis. Egyptian Journal of Rheumatology and Clinical Immunology. 2016; 4(1): 68-80.

21. Berner C, Erlacher L, Fenzl KH, Dorner TE. Medication adherence and coping strategies in patients with rheumatoid arthritis: A cross-sectional study. International Journal of Rheumatology. 2019; 2019:1-8.

22. Dabaghian FH, Rassouli M, Sadighi J, Ghods R. Adherence to prescribed medications of Iranian traditional medicine in a group of patients with chronic disease. Journal of research in pharmacy practice. 2016; 5(1): 52-7.

23. Sharma S, Roshi, Tandon VR, Mahajan A. A study evaluating adherence and compliance of antirheumatic drugs in women suffering from rheumatoid arthritis. Journal of clinical and diagnostic research. 2015; 9(11): 1-4.

24. Xia Y, Yin R, Fu T, Zhang L, Zhang Q, Guo G, et al. Treatment adherence to disease-modifying antirheumatic drugs in Chinese patients with rheumatoid arthritis. Patient preference and adherence. 2016; 10: 735-42.

25. Murage MJ, Tongbram V, Feldman SR, Malatestinic WN, Larmore CJ, Muram TM, et al. Medication adherence and persistence in patients with rheumatoid arthritis, psoriasis, and psoriatic arthritis: a systematic literature review. Patient preference and adherence. 2018; 12:1483-503. 


$$
\text { דوخته }
$$

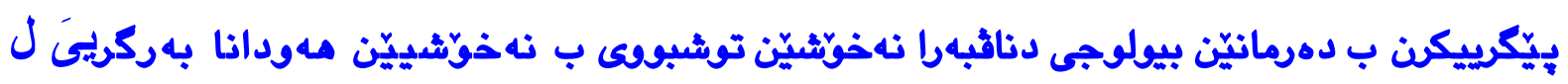

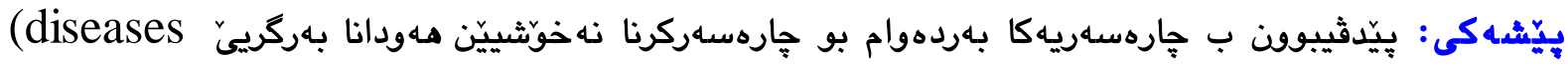
inflammatory mediated-immune

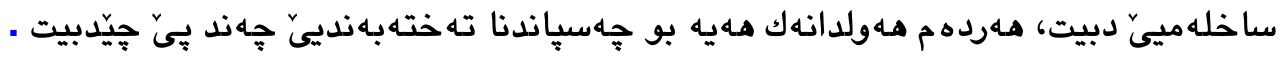

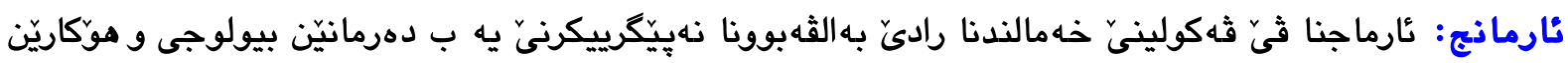

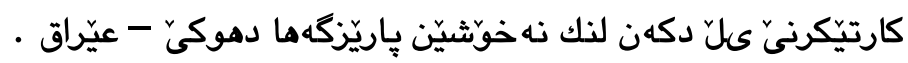

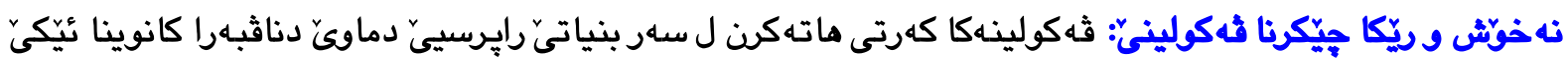

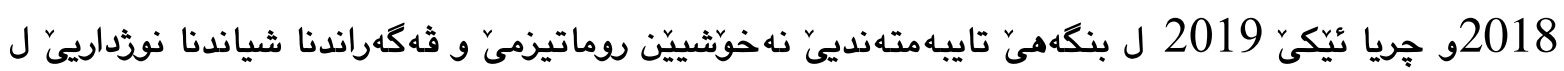

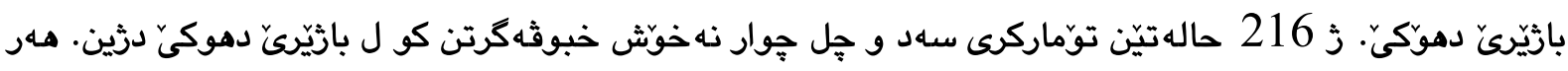
يُّك ثوان توشى نهخوّثيىّ بوويه بو ماويّ )12 )ههيثان ب كيّمى. ئهوان دهرمانيّن بيولوجى بكاردئينان Etanercept

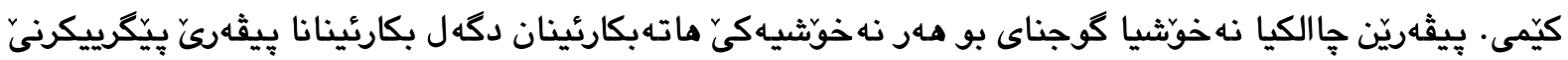

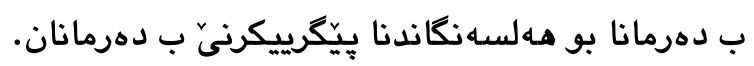

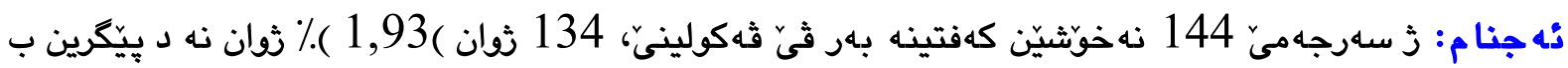

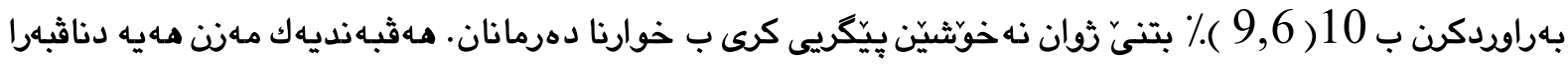

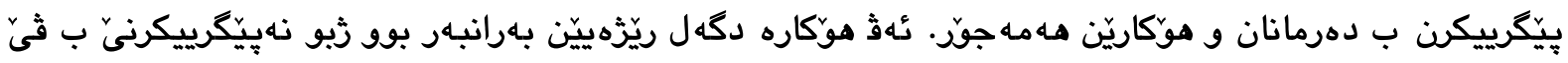

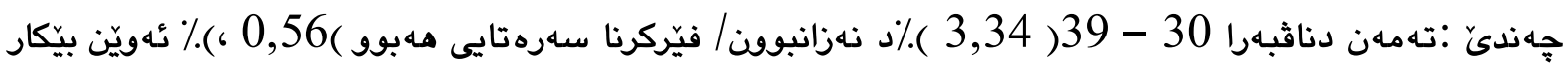

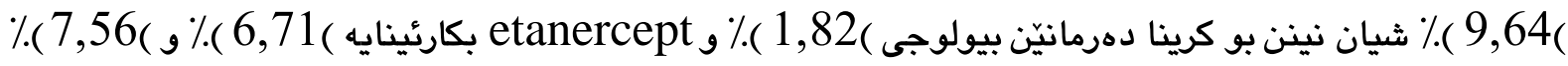
دهرمانيّن بيولوجى بو كيمرت ذ جار سالن بكاردئينان

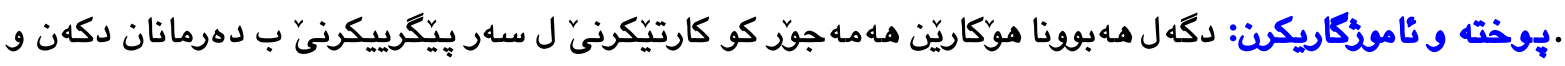

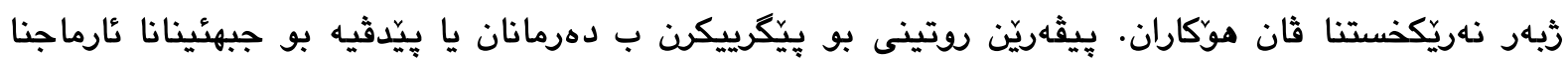
جارهسهريا داخازكرى. 


\section{الخلاصة}

اللتزام باألدوية البيولوجية بين المرضى المصابين باألمراض اللتهابية المناعية في محافظة دهوك

خلفية البحث: إن الحاجة إلى عالج مستمر لعالج الألمراض اللتهابية المناعية inflammatory يشكل تحِد يو اجه مقدمي الرعاية الصحية، حيث توجد دائماً محاولة الصنة لتحقيق التثيت سريرية قدر اإلمكان.

الهُف: هدفت هذه الدراسة إلى تقدير مدى انتشار عدم اللتنز ام بالعقاقير البيولوجية و العو امل المؤثرة

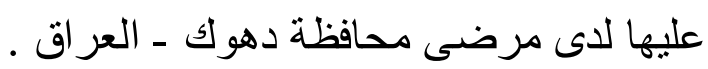

المرضى و طريقة عمل البحث : أجريت در اسة مقطعية قائمة على أساس الإستييان خالل الفترة الممتدة

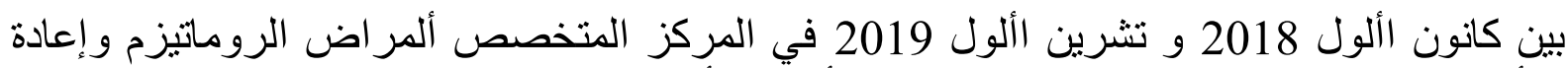

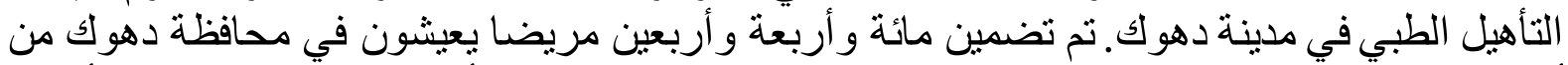

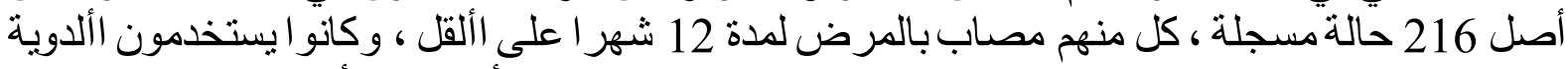

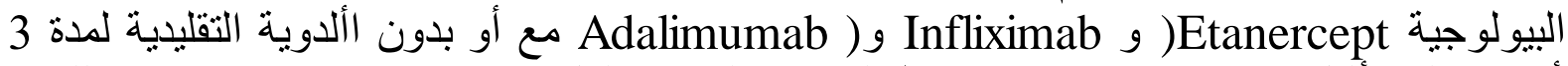
أشهر على الألقل. تم استخدام مقاييس نثاط المرض المناسبة لكل مرض، مع استخدام مقياس اللتز ام باألدوية لتقييم اللتز ام باألدوية .

النتائج: من إجمالي مريضا 144 مشمولين في هذه الدراسة ، كان 134( 134 (193 )٪منهم غير ملتزمين

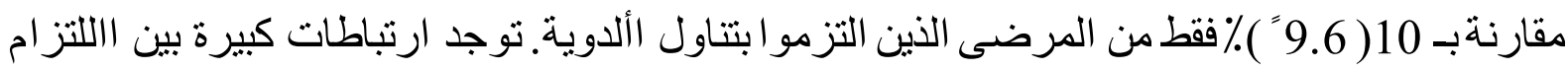

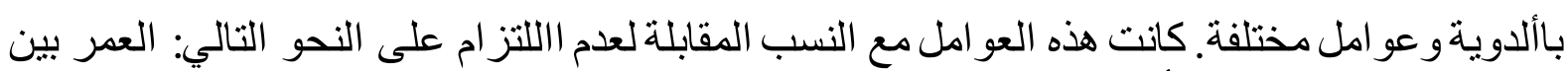

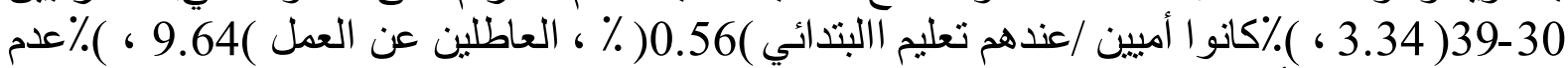

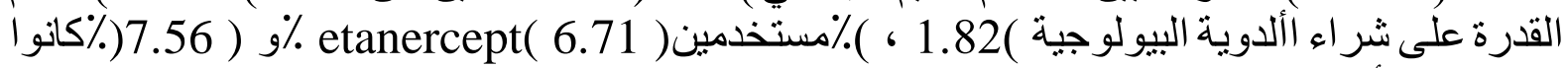

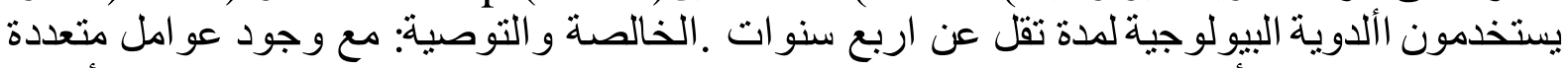

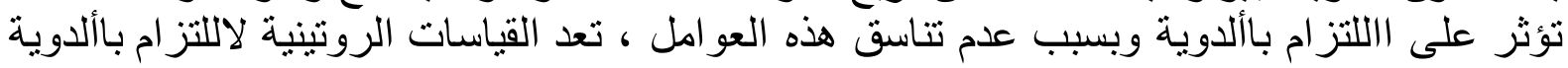
ضرورية لتحقيق الهذف العالجي المطلوب. 